\title{
The 80-year history of the professional associations of nutritionists in Brazil: A historical-documentary analysis
}

\author{
As entidades de classe na história de 80 anos \\ do nutricionista no Brasil: uma \\ análise histórico-documental
}

\author{
Francisco de Assis Guedes de VASCONCELOS ${ }^{1}$ iD 0000-0002-6162-8067 \\ Liliana Paula BRICARELLO1 (D) 0000-0001-5155-0107 \\ Nilce Maria da Silva Campos COSTA2 (D) 0000-0003-2531-1430 \\ Bibiana Arantes MORAES² (iD) 0000-0001-9312-4595

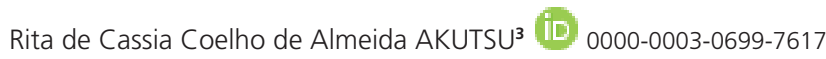

\section{A B S T R A C T}

\section{Objective}

To carry out a mapping of the historical trajectory of the professional associations of nutritionists (scientific associations, councils and professional labor unions) in Brazil.

\section{Methods}

The study consists of a historical-documentary analysis. To obtain the data, information and documents, the websites of the Federal Council of Nutritionists; Brazilian Association of Food and Nutrition; National Federation of Nutritionists and Nutritionists' Unions were browsed. A systematic bibliographic survey was carried out in the databases of the Scientific Electronic Library Online and National Library of Medicine to retrieve scientific articles about the associations of nutritionists in Brazil over the 80 years of their history, focusing on the last ten years.

1 Universidade Federal de Santa Catarina, Centro de Ciências da Saúde, Departamento de Nutrição. Campus Universitário, s/n., Trindade, 88040-9000, Florianópolis, SC, Brasil. Correspondence to: FAG VASCONCELOS. E-mail: <f.vasconcelos@ufsc.br>.

2 Universidade Federal de Goiás, Programa de Pós-Graduação em Ciências da Saúde, Departamento de Medicina. Goiânia, GO, Brasil.

3 Universidade de Brasília, Faculdade de Ciências da Saúde, Departamento de Nutrição. Brasília, DF, Brasil.

How to cite this article

Vasconcelos FAG, Bricarello LP, Costa NMSC, Moraes BA, Akutsu RCC. The 80-year history of the professional associations of nutritionists in Brazil: A historical-documentary analysis. Rev Nutr. 2019;32:e180160. http://dx.doi.org/10.1590/1678-9 $865201932 e 180160$ 


\section{Results}

The historical analysis indicates that, over the course of eighty years, there has been strengthening of professional associations of nutritionists and achievements concerning training regulation, professional practice, fields of work and working conditions. The labor reform act of 2017 reduces the rights related to working conditions, creating setbacks in the achievements of nutritionists.

\section{Conclusion}

The professional associations of nutritionists have played an important role in the process of professionalization and legitimacy of training and performance of the profession in the country. There are indications of the unified performance of professional associations, but it is still incipient and scarce. Nowadays, unified, transparent and committed action of these professional associations is imperative for the professionalization and improvements of the working conditions of Brazilian nutritionists.

Keywords: Health Occupation. Nutritionist. Professional Council. Scientific Associations. Syndicate.

\section{R E S U M O}

\section{Objetivo}

Realizar mapeamento da trajetória histórica das entidades de classe do nutricionista (associações científicas, conselhos e sindicatos profissionais) no Brasil.

\section{Métodos}

O estudo consiste em uma análise histórico-documental. Para obtenção dos dados, informações e documentos foram feitas visitas aos sítios eletrônicos do Conselho Federal de Nutricionistas; Associação Brasileira de Alimentação e Nutrição; Federação Nacional de Nutricionistas e Sindicatos de Nutricionistas. Realizou-se levantamento bibliográfico sistematizado nas bases Scientific Electronic Library Online e National Library of Medicine para capturar artigos científicos sobre a temática no Brasil ao longo dos 80 anos de sua história, com ênfase nos últimos dez anos.

\section{Resultados}

A análise histórica da Associação Brasileira de Alimentação e Nutrição, do Sistema Conselho Federal/Conselhos Regionais de Nutricionistas e da Federação Nacional de Nutricionistas/Sindicatos de Nutricionistas indica que, ao longo da trajetória de oitenta anos, houve fortalecimento das entidades de classe, com várias conquistas no arcabouço de regulamentação da formação, exercício profissional, campos de atuação e condições de trabalho. A reforma trabalhista, instituída em 2017, imprime redução de direitos relativos às condições de trabalho, acenando para retrocessos nas conquistas trabalhistas do nutricionista.

\section{Conclusão}

As entidades de classes do nutricionista têm desempenhado relevante papel no processo de valorização e legitimidade da formação e atuação da profissão no país. Há indícios da atuação unificada das entidades de classe, mas ainda incipientes e pontuais. Na atualidade, urge uma atuação unificada, transparente e comprometida destas entidades de classe em busca de valorização da profissão e melhorias das condições de trabalho do nutricionista brasileiro.

Palavras-chave: Ocupações em Saúde. Nutricionista. Conselho Profissional. Associações Científicas. Sindicato.

\section{NTROD U C TION}

The institutionalized process of the nutrition profession will have 80 years of history in Brazil in 2019. The first nutrition courses were established in 1939 for the training of nutritionists-dieticians, which were the beginning of the current undergraduate programs in Nutrition [1-4].

Professional associations have played an essential role in the process of organizing, mobilizing and ensuring the regulation and legitimacy of the nutrition profession in Brazil [1-5]. Professional associations are entities whose members or associates practice the same professional activity. In 
Brazil, professional associations include councils, associations and unions. Councils (federal and regional) are responsible for regulating and supervising the activities of the profession; associations are technical-scientific and socio-cultural institutions that focus on professionalization; and labor unions are institutions that protect the rights and common professional interests of workers (income, working hours and other labor conditions) $[4,6]$.

The present article is based on the theoretical assumption that within the complex field of disputes in the process of establishing Nutrition as a scientific (Science) and professional field (labor or profession), the professional associations of nutritionists have played an important civil, ethical, technical, scientific, political and union's role, not only concerning the interests of legitimacy, identity, corporation and professionalization, but above all, protecting and improving the food and nutrition conditions of the Brazilian society [7].

Over the last five years, although different studies on the professional performance of nutritionists have been published in Brazil [8-14], no studies have investigated the professional associations of nutritionists. Thus, the aim of the article is to pinpoint the historical trajectory of the professional associations of nutritionists in Brazil.

\section{METHODS}

This historical-documentary analysis $[15,16]$ seeks to summarize the trajectory of professional associations of nutritionists in Brazil throughout its 80 years of history.

To obtain the data, information and documents, exploratory browsing of the following websites of professional associations of nutritionists in Brazil was carried out: (1) Conselho Federal de Nutricionistas (CFN, Federal Council of Nutritionists) (http://www.cfn.org.br/) and the ten Conselho Regionais de Nutricionistas (CRN, Regional Councils of Nutritionists) under its jurisdiction; (2) Associação Brasileira de Nutrição (ASBRAN, Brazilian Association of Nutrition) (http://www.asbran. org.br/) and the network of affiliated state associations; and (3) Federação Nacional dos Nutricionistas (FNN, National Federation of Nutritionists) (http://www.fnn.org.br/) and labor unions.

With the purpose of retrieving scientific articles on the subject of professional associations of nutritionists in Brazil, published over the last ten years, a systematic bibliographic survey was carried out in the databases of the Scientific Electronic Library Online (SciELO) and the National Library of Medicine (PubMed) using the following uniterms: "nutritionist", "profession", "work", "labor market", "history", "association", "council", "union", "professional associations", "professional entity", "ethics", "professional ethics" and "science", in isolation, or combining two or more of these uniterms in Portuguese and English.

\section{The historical trajectory of the Brazilian Association of Nutrition: August 31, 1949 To June 2018}

ASBRAN, a scientific-cultural association, was founded in Rio de Janeiro in August 1949 as the Associação Brasileira de Nutricionistas (ABN, Brazilian Association of Nutritionists). ABN was the first association that represented and protected the interests of nutritionists/dietitians and conducted studies and research in the field of Nutrition $[1,3,4]$.

ABN was active from 1949 to 1972, when the Federação Brasileira das Associações de Nutricionistas (FEBRAN, Brazilian Federation of Nutritionists) was established, also with a technical- 
scientific and cultural nature, bringing together state associations of nutritionists from different federative units of the country $[1,3,4]$.

FEBRAN changed its name to ASBRAN in 1990 to adapt to the new civilian reality of the field of Nutrition, as the CFN/CRN System and the Labor Unions/FNN then existed formally. By legal requirement of civil societies, the term 'federation' corresponds to trade union organizations, being incoherent with the regulations and history of academic-scientific institutions [1,4]. There was a transition period from FEBRAN to ASBRAN, from 1990 to 1994, during which both institutions coexisted $[1,4]$.

ASBRAN is considered a non-profit private legal entity, responsible for uniting professionals in the field of Nutrition with the purpose of providing professional training and improvement by promoting events, courses, publications, work groups, etc. ASBRAN consists of members affiliated to the Nutrition State Associations and members include nutritionists, technicians and nutrition students, as well as a network of 10 affiliated state institutions [17].

It should be noted that the association representing the category of nutritionists, whether ABN, FEBRAN or ASBRAN, has always played a leading role in achieving significant accomplishments for the professional category. Among these achievements, we must mention: (1) ABN's pursuit for the recognition of undergraduate nutrition courses and establishment of the first minimum curriculum for training $[1,3,4]$; and (2) pursuit for the regulation of the profession, which resulted in Law No.5.276, enacted in 1967 [18], when it was replaced and repealed by Law No.8.234 in 1991, which now regulates the nutrition profession in Brazil [19].

During the era of FEBRAN, and due to its influence and state affiliates, the Federal and Regional Councils of Nutritionists (Law No.6.583) were founded in 1978, and the process of professional associations (or pre-union associations) was initiated, which would later become labor unions $[4,20]$.

In the 1970s and 1980s, events were organized by FEBRAN [2]. Since the 1950s, ASBRAN has been promoting the Congresso Brasileiro de Nutrição (CONBRAN, Brazilian Congress of Nutrition) every two years, with the purpose of promoting discussions and update of technical and scientific issues, as well as debates on trends in food and nutrition in Brazil $[1,2,17]$.

ASBRAN has discussed topics related to food and nutrition in the country, such as hunger and obesity in individuals and/or populations and has endeavored to promote professional qualification, food and nutritional security as well as contributing to the human right to adequate food. It remains dedicated to the technical-scientific development in the field of food and nutrition and publications and studies of nutritionists have been published on the electronic platform of its scientific journal since 2006 (RASBRAN) [17]. In partnership with CFN, through Resolution No.4.16/2008, ASBRAN has endorsed specialist programs in the fields of Collective Nutrition, Clinical Nutrition, Collective Health, Nutrition in Sports, and Phytotherapy as of 2015 [21]. In view of the increasing demand for Nutrition programs in Brazil over the last few decades, nutrition and food security have been discussed in subdivisions. To ensure the human right to adequate food, ASBRAN has worked with the following organizations: Comissão Interministerial de Alimentação e Nutrição (Interministerial Commission for Food and Nutrition); Câmara de Regulação do Trabalho em Saúde (Board on Health Workforce Regulation); Conselho de Segurança Alimentar e Nutricional (Council on Food and Nutrition Security); Conselho Nacional de Saúde (National Health Council); Fórum Brasileiro de Soberania e Segurança Alimentar e Nutricional (Brazilian Sovereignty and Food and Nutrition Security Forum); Fórum Permanente MERCOSUL para o Trabalho em Saúde (Permanent MERCOSUL Forum for Health Work); Comissão Nacional de Residência Multiprofissional em Saúde (National Multiprofessional Residence in 
Health); Fórum das Entidades Nacionais dos Trabalhadores da Área de Saúde (Forum of the national entities of health workers); and the Frente pela Regulação da Publicidade de Alimentos (Movement for the Regulation of Food Advertising) [17].

In 2008, the Associação Brasileira de Educação em Nutrição (ABENUT, Brazilian Association of Nutrition Education) was founded to represent nutrition education institutions and the academic community in Brazil, which include professors and students and the Ministries of Education and Health, as well as other organized civil society entities [22].

\section{The historical trajectory of the Federal Council System of Nutritionists/Regional Councils of Nutritionists: October 1978 to June 2018}

In October 1978, with the enactment of Law No.6.583, nutritionists counted on a specific body that supervised, guided, disciplined and regulated the profession throughout the national territory in favor of the society $[4,18,20]$. The CFN and the CRN were established after the aforementioned law [20]. In January 1980, Decree No.84.444 was introduced to regulate the CFN/CRN system and establish its operating structure [23]. Currently, the nutrition profession in Brazil is under the responsibility of the CFN system and ten CRNs, who seek to establish a set of normative procedures, respecting the particularities of the different regions of the country [24].

The structure of the CFN/CRNs system, established under the Decree No.84.444 [23], consists of: (1) Plenary (deliberative body); (2) Executive Board (executive body); (3) Presidency (coordination and management body); (4) Permanent Committees - Ethics, Inspection, Accounts, Vocational Training, Communication and public bidding (guidance, discipline, support and advisory bodies); (5) Special and transitional committees and work groups; and (6) Technical sections [24].

As stated on its homepage, CFN's mission "is to contribute to the human right to adequate and healthy food, regulate and discipline the professional practice of nutritionists and technicians in Nutrition and dietitians, for professional practice based on ethics and committed to food and nutrition security for the benefit of society" [24].

In December 2017, the CFN/CRN system registered a total of 126,539 nutritionists under its jurisdiction, distributed throughout the national territory. The current CFN/CRN system consists of: CRN 1: Distrito Federal, Goiás, Mato Grosso, Tocantins - Head office: Brasília (DF); CRN 2: Rio Grande do Sul - Head office: Porto Alegre (RS); CRN 3: São Paulo and Mato Grosso do Sul - Head office: São Paulo (SP); CRN 4: Espírito Santo and Rio de Janeiro - Head office: Rio de Janeiro (RJ); CRN 5: Bahia and Sergipe - Head office: Salvador - (BA); CRN 6: Alagoas, Ceará, Maranhão, Paraíba, Pernambuco, Piauí, Rio Grande do Norte - Head office: Recife (PE); CRN 7: Acre, Amazonas, Rondônia, Pará, Roraima, Amapá - Head office: Belém (PA); CRN 8: Paraná - Head office: Curitiba (PR); CRN 9: Minas Gerais - Head office: Belo Horizonte (MG); e CRN 10: Santa Catarina - Head office: Florianópolis (SC) $[24,25]$.

The payment of the member fee to the Regional Council of the respective jurisdiction, as a body of the state, assures the legitimacy of the practice of the profession and operation of companies that employ nutritionists [23].

The first Code of Ethics of Brazilian Nutritionists was created in 1981 by the CFN. However, over the years, the code has undergone reformulations and its latest version, called the Code of Ethics and Conduct of Nutritionists, establishes the principles, responsibilities, rights and duties that must be recognized as the core requirements for the daily practice in all the areas of Nutrition. This edition 
(Resolution No.599/2018) [26], which replaced the Code published in 2004, brings innovations that take into account the advances and nuances of the professional's practice in the $21^{\text {st }}$ century.

An important milestone in the legislation of the profession occurred in December 2005, when the CFN issued Resolution No.380, which defined the areas of activity of nutritionists and their attributions and established numerical reference parameters per area of activity. This Resolution was revoked by the current Resolution No.600/18 [27] that establishes seven areas of activity, as follows: Nutrition in Collective Food; Clinical Nutrition; Nutrition in Sports and Physical Exercise; Nutrition in Collective Health; Nutrition in Food Production, Industry and Food Commerce; and Nutrition in Teaching, Research and Extension.

\section{The historical trajectory of the National Federation of Nutritionists/Labor Unions: June 1982 to June 2018}

The Brazilian labor union structure consists for labor unions, federations, confederations and central labor unions [28]. There are currently 23 labor unions, 14 of which are affiliated to FNN, affiliated to the National Confederation of Liberal Professionals, of which it is a board member, and affiliated to the General Union of Workers. It should be noted that labor unions do not follow the determinations of FNN when becoming affiliated to a particular labor union, and some labor unions of nutritionists are affiliated to other union federations [28-30].

The FNN was founded in 1989 by the labor unions of Nutritionists from Rio Grande do Sul, Federal District, Alagoas, São Paulo, Pernambuco and Rio de Janeiro, when the bylaws were approved. The first board consisted of labor unions in Rio Grande do Sul (presidency), Rio de Janeiro (secretary) and Alagoas (treasury) [29,31].

The political context of the founding of FNN coincided with the re-democratization of the country and strengthening of labor unions, federations, confederations and central labor unions for all professional categories. Before that, the granting of union licenses was a slow and costly process [31].

Of the six labor unions of the FNN, Rio Grande do Sul was founded in 1982. All labor unions at that time were professional associations, pre-union entities, which were prior to the granting of the union license $[29,31]$. The labor union of Nutritionists of São Paulo was founded in 1982 as an association and the union license was only granted in 1988. The next union licenses were granted to the labor unions in Rio de Janeiro (1984), Pernambuco (1986), Distrito Federal (1986) and Alagoas (1989) $[29,31]$.

The legislation only allows one union representative per federation unit. Although the Union of Nutritionists of the Federal District is one of the founders of the FNN, it has been dissolved, but it might be reactivated [28-30].

During the second administration of the FNN (1995-1988), there were offices in: Mato Grosso do Sul, Rio Grande do Norte, Sergipe, Espírito Santo, Paraíba, Ceará, Minas Gerais, Amapá, Rondônia, Pará and Piauí. These offices were created to begin the process of establishing labor unions in those states [29].

During the third administration of the FNN (1999-2002), the labor unions in Rio Grande do Norte, Paraíba and Ceará were founded, and the labor union in the Federal District was reactivated. In a joint effort with other nutrition entities, the FNN sought to include professionals in the Programa de Saúde da Família (PSF, Family Health Program) and health insurance plans. Although different 
entities were pursuing rights for professionals, there were divergences among the entities, which sometimes placed them on opposite sides, even on opposite legal sides [29].

In the fourth administration (2003-2007), the labor unions in Mato Grosso do Sul, Amapá, Santa Catarina and Minas Gerais were founded, as well as an office in Piauí. The joint work of the national entities (FNN, CFN and ASBRAN) was implemented during the Encontro Nacional das Entidades dos Nutricionistas (ENAEN, National Meeting of Nutrition Entities). The first collective negotiations with employers began through the FNN in the states of Santa Catarina and Paraná [29].

In the fifth administration (2008-2012), due to political differences, the labor unions of Pernambuco, São Paulo, Rio de Janeiro, Rio Grande do Sul, Bahia, Alagoas, Sergipe, Pará and Mato Grosso do Sul were dissolved. These labor unions have since been trying to create a new federation, FEBRAN [29].

The current administration began in 2013 and it has adopted a position of consolidation of the labor unions in the remaining states, in addition to the rapprochement with the CFN/CRN and ASBRAN system. The FNN is currently affiliated to the labor unions in Santa Catarina, Paraná, Mato Grosso, Goiás, Minas Gerais, Espírito Santo, Rio Grande do Norte, Paraíba, Ceará, Maranhão, Piauí, Tocantins, Amapá and the Federal District, which is still undergoing a restructuring process. The states of Amazonas, Acre, Roraima and Rondônia do not have labor unions yet [29].

Since the founding of labor unions and the FNN, the maintenance of activities has been assured by union fees, which consisted of a day's work that is compulsorily collected in March and passed on to the unions in the following month. Although this was the most important source of funding for the labor union movement, it was not the only one. The labor unions also have as a source of income the dues paid to the unions and a day's work, if declared, by the affiliates. The other entities collect in succession, that is, the labor unions pay the affiliated federations and centers, and federations pay the affiliated confederations [30].

The Labor Reform of 2017 maintained the unity of labor unions but established that the dues equivalent to a day's work should not be compulsory. In addition, the reform made other changes such as the telework contracts, intermittent work contracts, extension of part-time contracts, established service contracts for front-end activities (outsourcing), restricted equal rights to a few items, and allowed independent work contracts [32].

The Labor Reform therefore included elements that facilitate dismissal, change the duration of daily work, deregulate, reduce or 'flexibilize' rights related to working conditions. These changes do not only affect the representativity of labor unions, but they also reduce the union revenues and the ability to protect workers in general, which among them include the nutritionists [32].

\section{CONCLUSION}

Throughout the eighty years of history, professional associations of nutritionists have been structured into different organizational forms, based on the specific and characteristic objectives of each entity, although they sometimes overlap, complement or replace each other due to the interests of the professional category.

The current ASBRAN, a pioneer in the fight to defend the regulation and professionalization of nutritionists in Brazil, will complete seventy years on August 31, 2019 since its foundation. For three decades (1949-1978) it has been the only entity that represents and protects the interests 
of nutritionists in the country. Since then, other entities have jointly protected the interests of the category. ASBRAN and network state affiliates depend on the non-compulsory financial contribution of affiliates. Currently, ASBRAN consists of network of only ten affiliates and most of the federal units of the country do not have the representation of a technical-scientific entity. In the national context, ASBRAN has sought to promote technical and scientific development in the field of food and nutrition by promoting scientific events such as CONBRAN, participating in forums to protect the human right to adequate food, as well as endorsing specialist programs in nutrition.

The CFN/CRN system completed 40 years in October 2018. The CRN are indirect public administration authorities that financially depend on the compulsory contribution of registered professionals. Throughout its historical trajectory, the CFN/CRNs system has acted throughout the national territory, not only by supervising the profession, but also organizing, mobilizing and ensuring the professionalization of nutritionists by defending their interests and, above all, ensuring adequate food and nutrition conditions for the Brazilian population.

The FNN is a professional association with a more recent history and it will complete thirty years in September 2019, although the first labor union of Brazilian nutritionists was created in 1982. Throughout its history, FNN/Labor Unions of Nutritionists have been composed of organizations that defend the labor rights and interests of Brazilian nutritionists. If non-affiliation to the only existing federation can be considered a salutary process, which denotes autonomy and political diversity of the professional category, the non-existence of a labor union in the federative unit can be detrimental to ensure the rights and working conditions of the professionals in these states.

After the Labor Reform act of 2017, public regulation of labor has been reduced, which had been achieved and developed throughout the history of the wage labor market in Brazil. There is a growing withdrawal of the role of the state and labor unions regarding the regulation of labor relationships, which leave the worker unprotected when negotiating or establishing working conditions with employers. The nutritionist, as one of the professional categories of the Brazilian working class, will also be affected by these labor law changes.

In sum, professional associations of nutritionists have played an important role in the professionalization process and legitimacy of training and performance of the profession in the country. There are indications of the unified performance of professional associations, but they are still incipient and scarce. Nowadays, a unified, transparent and committed action of professional associations of nutritionists in search of professionalization and improvements for their working conditions is imperative. From a broader perspective, it is crucial to initiate a process of technicalscientific and political mobilization with all nutritionists in favor of adequate and sustainable food and nutrition conditions for all Brazilians.

\section{CONTRIBUTORS}

FAG VASCONCELOS contributed to the design, research and writing of the manuscript, as well as the critical review and approval of the version to be published; LP BRICARELLO, NMSC COSTA, BA MORAES and RCCA AKUTSU contributed to the research and writing of the article, critical review and approval of the version to be published.

\section{REFERENCES}

1. Associação Brasileira de Nutrição. Histórico do nutricionista no Brasil - 1939 a 1989: coletânea de depoimentos e documentos. São Paulo: Atheneu; 1991. 
2. Costa N. A formação do nutricionista: educação e contradição. Goiânia: Editora UFG; 2001.

3. Vasconcelos FAG. O nutricionista no Brasil: uma análise histórica. Rev Nutr. 2002;15(2):127-38. http://dx.doi. org/10.1590/S1415-52732002000200001

4. Vasconcelos FAG, Calado CLA. Profissão nutricionista: 70 anos de história no Brasil. Rev Nutr. 2011;24(4):605-17. http://dx.doi.org/10.1590/S1415-52732011000400009

5. Akutsu RC. Brazilian dieticians: Professional and demographic profiles. Rev Nutr. 2008;21(1):7-19. http:// dx.doi.org/10.1590/S1415-52732008000100002

6. Queiroz Neto L. A pertinência temática como requisito da legitimidade ativa para o processo objetivo de controle abstrato de normas. Rev TRF. 2005;21(1):1-17.

7. Bourdieu P. O poder simbólico. 2a ed. Rio de Janeiro: Bertrand Brasil; 1998.

8. Aguiar CB, Costa NMSC. Formação e atuação de nutricionistas dos Núcleos de Apoio à Saúde da Família. Rev Nutr. 2015;28(2):207-16. http://dx.doi.org/10.1590/1415-52732015000200009

9. Borelli M, Domene SMÁ, Mais LA, Pavan J, Taddei JAAC. A inserção do nutricionista na Atenção Básica: uma proposta para o matriciamento da atenção nutricional. Ciênc Saúde Coletiva. 2015;20(9):2765-78.

10. Chaves LG, Santana TCM, Gabriel CG, Vasconcelos FAG. Reflexões sobre a atuação do nutricionista no Programa Nacional de Alimentação Escolar no Brasil. Ciênc Saúde Coletiva. 2013;18(4):917-26.

11. Corrêa RS, Rockett FC, Rocha PB, Silva VL, Oliveira VR. Atuação do nutricionista no Programa Nacional de Alimentação Escolar na região sul do Brasil. Ciênc Saúde Coletiva. 2017;22(2):563-74.

12. Rodrigues DCM, Bosi MLM. O lugar do nutricionista nos Núcleos de Apoio à Saúde da Família. Rev Nutr. 2014;27(6):735-46. http://dx.doi.org/10.1590/1415-52732014000600008

13. Souza AA, Bezerra OMPA, Bonomo E, Silva CAM. Atuação de nutricionistas responsáveis técnicos pela alimentação escolar de municípios de Minas Gerais e Espírito Santo. Ciênc Saúde Coletiva. 2017;22(2):593-606.

14. Vieira VL, Cervato-Mancuso AM. Professional training in the context of food and nutrition security. Prim Health Care Res Dev. 2015;16(5):540-4.

15. Mattar J. Metodologia científica na era da informática. 3a ed. São Paulo: Saraiva; 2008.

16. Merlo F, Konrad GVR. Documento, história e memória: a importância da preservação do patrimônio documental para o acesso à informação. Inf Inf. 2015;20(1):26-42.

17. Associação Brasileira de Nutrição. Brasília; 2018 [citado 2018 jun 15]. Disponível em: http://www.asbran. org.br

18. Câmara dos Deputados (Brasil). Lei n5.276, de 24 de abril de 1967. Dispõe sobre a profissão de Nutricionista, regula o seu exercício, e dá outras providências. Brasília: Congresso Nacional; 1967 [citado 2018 jun 10]. Disponível em: http://www2.camara.leg.br/legin/fed/lei/1960-1969/lei-5276-24-abril-1967-358700-normapl.html

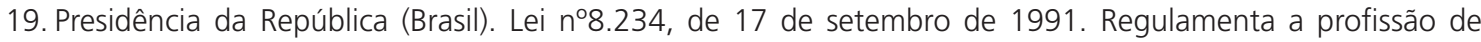
nutricionista e determina outras providências. Brasília: Diário Oficial da União; 1991 [citado 2018 set. 27]. Disponível em: http://www.cfn.org.br/index.php/lei-no-8-234-de-17-de-setembro-de-1-991-dou-18091991-2/

20. Presidência da República (Brasil). Lei n6.583, de 20 de outubro 1978. Cria os Conselhos Federal e Regionais de Nutricionistas, regula o seu funcionamento, e dá outras providências. Brasília: Presidência da República; 1978 [citado 2018 jun 10]. Disponível em: http://www.planalto.gov.br/ccivil_03/leis/1970-1979/L6583.htm

21. Conselho Federal de Nutricionistas. Resolução CFN n556, de 11 de abril de 2015. Altera as resoluções n416, de 2008, e n525, de 2013, e acrescenta disposições à regulamentação da prática da Fitoterapia para nutricionista como complemento da prescrição dietética. Brasília: CFN; 2015.

22. Veloso TCMA, Antunes MT, Peixoto OMC. A Associação Brasileira de Educação em Nutrição e sua inserção no FNEPAS. Cad FNEPAS. 2012;2:29-37.

23. Câmara dos Deputados (Brasil). Decreto $n^{\circ} 84.444$, de 30 de janeiro de 1980. Regulamenta a Lei $n^{\circ} 6.583$, de 20 de outubro de 1978, que cria os Conselhos Federal e Regionais de Nutricionistas, regula o seu funcionamento e da outras providências. Brasília: Congresso Nacional; 1980 [citado 2018 jun 10]. Disponível em: http://www2.camara.leg.br/legin/fed/decret/1980-1987/decreto-84444-30-janeiro-1980-433856publicacaooriginal-1-pe.html 
24. Conselho Federal de Nutricionistas. Sobre o CFN. Brasília: CFN; 2018 [citado 2018 jun 10]. Disponível em: http://www.cfn.org.br/index.php/sobre-nos/

25. Conselho Federal de Nutricionistas. Quadro estatístico do $4^{\circ}$ trimestre/2017 (1\%/10/2017 a 31/12/2017). Brasília: CFN; 2017 [citado 2018 jun 10]. Disponível em: http://wcww.cfn.org.br/index.php/estatistica/

26. Conselho Federal de Nutricionistas. Resolução n599, de 25 de fevereiro de 2018. Aprova o Código de Ética e de Conduta do Nutricionista e dá outras providências. Brasília: CFN; 2018 [citado 2018 jun 22]. Disponível em: http://www.cfn.org.br/wp-content/uploads/resolucoes/Res_599_2018.htm

27. Conselho Federal de Nutricionistas. Resolução $n^{\circ} 600$, de 25 de fevereiro de 2018. Dispõe sobre a definição das áreas de atuação do nutricionista e suas atribuições, indica parâmetros numéricos mínimos de referência, por área de atuação, para a efetividade dos serviços prestados à sociedade e dá outras providências. Brasília: CFN; 2018 [citado 2018 jun 22]. Disponível em: http://www.cfn.org.br/wp-content/uploads/resolucoes/ Res_600_2018.htm

28. Sindicato dos Servidores da Tributação, Fiscalização e Arrecadação do estado de Minas Gerais. Rádio SINFFAZFISCO: conheça a estrutura sindical brasileira. Belo Horizonte: SINFFAZFISCO; 2017 [citado 2018 set 27]. Disponível em: https://www.sinffazfisco.org.br/radio-sinffazfisco-conheca-a-estrutura-sindical-brasileira/

29. Federação Nacional dos Nutricionistas. Histórico. Brasília: FNN; 2018 [citado 2018 jul 5]. Disponível em: http://www.fnn.org.br/Historico

30. Melo CVB. Contribuição sindical. Brasília: Câmara dos Deputados; 2005 [citado 2018 jul 5]. Disponível em: http://bd.camara.gov.br/bd/handle/bdcamara/1204

31. Federação Nacional dos Nutricionistas. Ata de fundação. Recife: FNN; 1989.

32. Departamento Intersindical de Estatística e Estudos Socioeconômicos. A reforma trabalhista e os impactos para as relações de trabalho no Brasil. Nota Técnica n¹78. São Paulo: Dieese; 2017 [citado 2018 jul 5]. Disponível em: https://www.dieese.org.br/notatecnica/2017/notaTec178reformaTrabalhista.pdf 